\title{
Exchange Rate Pass - Through in Algeria
}

\author{
Kamel Si Mohammed
}

Email: simohammed_k@yahoo.fr

\author{
Ali Bendob \\ Lahcen Djediden
}

Houaria Mebsout

Department of Economics and Management, Ain Temouchent University Centre, Ain Temouchent, Algeria

\section{Doi:10.5901/mjss.2015.v6n2p195}

\section{Abstract}

This paper examines the exchange rate pass-through on producer and consumer price indexes in the Algerian economy through an empirical analysis using a VAR Model (Vector Autoregressive Model) upon quarterly data for the 2002-2011. The empirical findings show that the consumer price increases in response to an appreciate foreign exchange rates against the Algerian Dinar, while the pass-through of Euro against the Algeria Dinar exchange rate is 'complete' and more increasing in the time horizon compared the pass-through of US dollar IDZ exchange rate. In the contrast, the exchange rate pass-through involves a negligible reaction on producer price index (PPI). In the second step of the variance decomposition estimate, the magnitude contribution of demand shocks to explain CPI and PPI change is ranges from $50 \%$ and $17 \%$ after thirty quarterly respectively, whereas supply shock (oil price) continue to contribute largely to CPI fluctuations (30\%) and quite modestly to PPI (5\%). For the main explanations can be explain these results are consist firstly by an increase in world commodity prices and dismantling Algerian trade barriers after entered into force of the Euro-Mediterranean Agreement establishing an Association without mentioning that this union is the largest trading partner about $1 / 2$ of the Algerian imports. Moreover, the quite modest of pass-through on producer prices clearly reflect the Dutch Disease effect on Algeria economy and highlighted how the manufacture sectors is underdeveloped, while it's emphasizes how the policy maker help to swell the Algerian imports instead of trying to curtailment by replacing with domestic production.

Keywords: Exchange rate pass-through, inflation, VAR Model, Algeria.

\section{Introduction}

As far as the Algerian exchange rate is concerned, since 1996 the central bank adopted a managed floating exchange rate after a long experience with the former regime (1974-1995) ${ }^{1}$ that was built upon a strong concentration of the US Dollar that ..played an important role due to its $98 \%$ in hydrocarbon export receipts Kamel . S et al; (2014). This new exchange rate policy ongoing by Algeria's government into recommendations of the International organizations as Monetary Fund (FMI) and the World Bank (IBRD) has been a failure. After the end the first decade of the new millennium, we can be seen clearly around $40 \%$ of business transaction carried out through the black market in informal sector when the gap between the official exchange rate of the Algerian Dinar against the Euro and that observed on the black market has exceeded to 40\%; Bouteldja A et al (2013).

In addition, we can be seen clearly The last major depreciation in the value of the Algerian Dinar since the adjustment program during in 1990s tell today have a direct impact on domestic price (finished goods and Imported inputs become more expensive into local currency: Goldberg and Knetter 1996) lead especially in open economic like Algeria when import rise every year. Average domestic price was 18.55\% in the early 1990s, when, after the end the first decade of the new Millennium and beginning of the second decade, inflation was characterized by increasing the inflation rates in levels to 6-8.5 percent.. (Figure 1).

\footnotetext{
${ }^{1}$ Algerian exchange rate was based upon a basket of 14 currencies.
} 


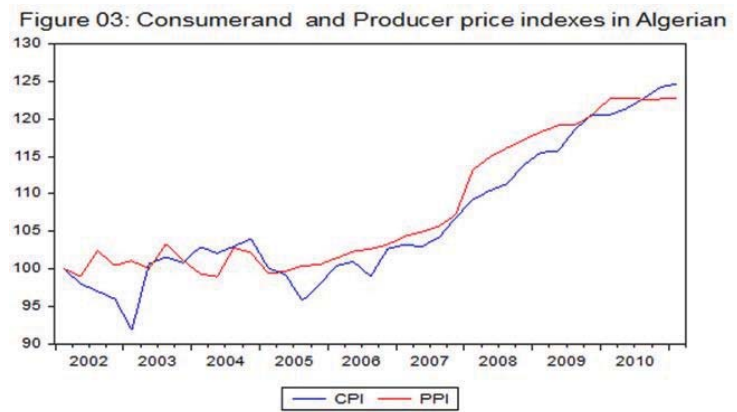

On the Contrary in the second decade (2000s), inflation had witnessed their lowest average at $3.2 \%$.the persist of inflation in their lowest level in this period Did not come by successful of Structural Adjustment Program, but oil and gas as dominant structure of the economy lead to increased macroeconomic stability. This sector accounted for $97 \%$ of exports between "2002 - 2011". (Figure 2), 32 to 45 percent of GDP and 46 to 70 percent of government revenue and trade openness is higher more than $60 \%$ in same period (Table 01).

Figure 2: Trade (Billions of Dollars)

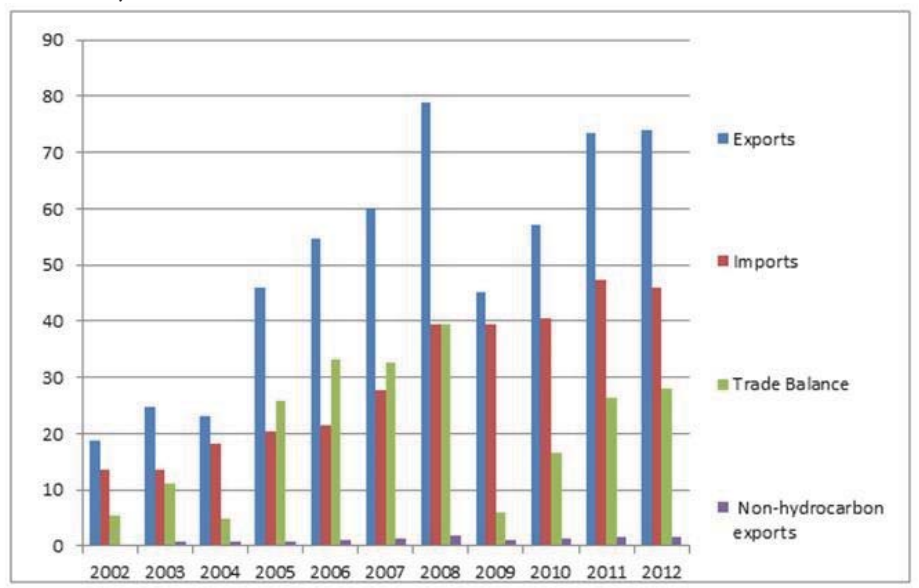

Source: World Development Indicators.

Table (1): GDP \& government revenues dependency on oil

\begin{tabular}{|l|c|c|c|c|c|c|c|c|c|}
\hline & 2004 & 2005 & 2006 & 2007 & 2008 & 2009 & 2010 & 2011 & 2012 \\
\hline Share of oil in GDP (\%) & 35.5 & 45 & 45.4 & 43.3 & 45.4 & 31.6 & 32.5 & 39 & 31.7 \\
\hline government expenditure (billions of dollars) & 44.4 & 46.1 & 50.8 & 57.6 & 73.9 & 67.4 & 79.5 & 81 & 91.4 \\
\hline Trade Openness (\%) & 58,1 & 64,8 & 64,9 & 64,6 & 69,4 & 60,2 & 61,1 & 71 & 53,9 \\
\hline
\end{tabular}

**Statistics Algeria, The ministry of Finance: http://www.mf.gov.dz/rubriques/15/Activités.html.

Source:* IMF Country Report of Algeria from 2004-2012.

The purpose of this paper seeks to examine the exchange rate pass-through on producer and consumer price indexes in the Algerian economy through an empirical analysis using a VAR Model (Vector Autoregressive Model) upon quarterly data for the 2002-2011. Proposal objectives mentioned address for a scientific audience, while, we try to clarify the contradictory situation between exchange rate and producer, consumer prices trend remains the main issue to be dealt with in this paper.

The rest of the paper is organized as follows. In section two we present a literature review on the relationship. Section three presents the model and the methodology, followed by the results and discussion in Section four, and finally, section five presents the main conclusion.

\section{Literature Review}

McCarthy, (1999) examined the impact of exchange rates and import prices on domestic PPI and CPI in nine developed countries from the period1976:1 to 1998:4. His results using Impulse responses and variance Decompositions of the VAR Model indicate that 5exchange rate and import price shocks have modest effects on domestic inflation. Many studies 
have inspired their work by a McCarthy's paper, Belaisch (2002) for Brazil found lower pass-through on domestic price compared with estimate in other studiers in Latin American and G-7 countries. Andreas Billmeir and Leo Bonato, (2002) pointed out in their study the response of $\mathrm{CPI}$ inflation to exchange rate pass-through in Croatia is greater than response of wholesale price index. Leigh and Rossi, (2002) carried out a similar analysis the pass-through in turkey to WPI is more pronounced compared to the pass-through to consumer prices (CPI). On the contrary, Nikolaty Gueorguiev, (2003), covered the period from June 1997 to January 2003 for demonstrating the large and the fast of exchange rate passthrough to producer price index compared the consumer price index.

José M Campa, Linda S. Goldberg, and José M. González-Mínguez (2005) showed the transmission of exchange rate pass-through to import prices in the Euro Area over the last fifteen years is high in the short and long run.

Rudrani B et al (2008) investigated the impact of a change in the nominal exchange rate on the wholesale and consumer price indexes from 1997 to 2007 in India. Theirs results established cointegrating relationships, after it finds that exchange rate pass-through into domestic prices in India is negligible and moderate effect on WPI . In the same country, Khundrakpa, (2007) and Ghosh and Rajan, (2007) used a cointegration technique to arrive at the conclusion that there any long-run co-integrating relation between exchange rate and inflation price.

Yelena $\mathrm{F}$ (2008) concludes that the recent reduction in the real exchange rate pass-through can be attributed in part to the low-inflation environment of the 1990s of fourteen OECD countries.

Siaw Frimpong and Anokye M. Adam( 2010) analyzed the effect of exchange rate changes on consumer prices in Ghana using vector auto-regression (VAR) models of the period 1990M01-2009M02. The authors found that the exchange rate pass-through to inflation is 'incomplete' and decreasing in Ghana.

Verena T et al (2010) suggested that the impulse response function of exchange rate pass through to consumer prices is the highest; followed by producer prices while exchange rate pass through to import prices is the lowest in small island economy of Mauritius using Quarterly data from 1999 to 2010 and the Structural Vector Autoregressive model.

Janine A et al (2012) examined the exchange rate Pass-through to the monthly import prices in South Africa during 1980-2009. Results of impulse response function implied by SVAR with the pass-through estimates from the singleequation analysis showed contradictory situation. At a 1-month horizon, the SVAR has a 0 response in contrast to around $4,5 \%$ for second method, while has 35\% for SVAR at around 54\% for the single-equation estimates after ten years.

Etsuro Shioji (2012) applied a TVP-VAR method to finds the exchange rate pass-through on the Japan's export prices increased, while it decline on both import and domestic prices during the 1980s

Nidhaleddine Ben Cheikh (2013) studied the pass-through of exchange rate in the context of the European Sovereign Debt Crisis for five heavily indebted namely Greece, Ireland, Italy, Portugal,and Spain using smooth transition regression (STR) models. His results show that there is an important effect of macroeconomic instability on the exchange rate pass-through.

Mototsugu Shintani, Akiko Terada-Hagiwara and Tomoyoshi Yabu (2013) detected an association relationship periods of low exchange rate pass-through and low inflation levels in USA.

\section{Model and Methodology}

\subsection{Definition of the VAR Model}

The Vector Auto Regression (VAR) is commonly used for forecasting systems of interrelated time series and for analyzing the dynamic impact of random disturbances on the system of variables. The VAR approach side steps the need for structural modeling by treating every endogenous variable in the system as a function of the lagged values of all of the endogenous variables in the system. Moreover, we choose the impulse responses and Variance decomposition for running the important sources and responses percent of $\mathrm{CPI}$ and PPI variances to Algerian exchange rate variation when, the change in local currency prices resulting from variations in the exchange rate for consumer and producer prices

The mathematical representation of a VAR is:

$y_{t}=A_{1} y_{t-1}+\ldots+A_{p y t-p}+B_{x t}+\varepsilon_{t}(1)$

Where $y_{t}$ is a $k$ vector of endogenous variables, $x_{t}$ is a $d$ vector of exogenous variables, $A_{1}, A_{p}$ and $B$ are matrices of coefficients to be estimated, $\varepsilon$ t and is a vector of innovations that may be contemporaneously correlated but are uncorrelated with their own lagged values and uncorrelated with all of the right-hand side variables.

\subsection{Our empirical specification}

Several studies adopting the VAR Model produce sensible impulse response function and variance decomposition in 
individual countries for obtaining shocks effect from exchange rate Pass-through to domestic price see (McCarthy (1999, 2000, Bhundia (2002) for South Africa, Leigh and Rossi (2002) for Turkey and Belaisch (2003) for Brazil....).

In this paper, we try to detect the macroeconomic factors behind the effect of exchange rate pass through on domestic price (CPI and PPI by applied the VAR Model based on McCarthy (1999), therefore and be taken into consideration the Algerian economy specific, our model negligible distribution chain of import and interest rate as small difference against the McCarthy original core model for many reason we try to developed in the results. We can be written the mathematical formulation as:

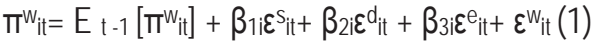

$$
\begin{aligned}
& \Pi^{c_{i t}}=E_{t-1}\left[\pi^{c_{i t}}+y_{1 i} \varepsilon_{i t}+y_{2 i} \varepsilon_{i t}+y_{3 i} \varepsilon_{i t}+\varepsilon^{c_{i t}}(2)\right. \\
& \pi^{\mathrm{oil}_{\mathrm{it}}}=\mathrm{E}_{\mathrm{t}-1}\left[\pi^{\mathrm{oi}} \mathrm{il}_{\mathrm{it}}\right]+\varepsilon^{\mathrm{s}_{\mathrm{it}}}(3) \\
& y_{i t}=E_{t-1}\left[y_{i t}\right]+a_{1 i} \varepsilon_{i t}+\varepsilon^{d_{i t}}(4) \\
& \Delta_{\text {eit }}=E_{t-1}\left[\Delta_{\text {eit }}\right]+b_{1 i \varepsilon} s_{i t}+b_{2 i} d_{\text {it }}+\varepsilon e_{i t}(5)
\end{aligned}
$$

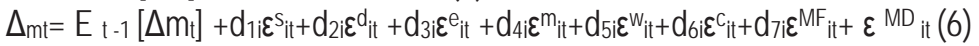

where $\pi^{w_{i t}}$ and $\pi^{c i t}$ are PPI and CPI inflation respectively in the period $t ; \varepsilon^{s}, \varepsilon^{d}$ and $\varepsilon^{e}$ are the supply, demand, and exchange rate shocks respectively, while $\varepsilon^{w_{i t}}$ and $\varepsilon^{c}$ it are the PPI, and CPI inflation shocks; whereas $E_{t-1}$ is the expectation of a variable based on the information set at the end of period t- 1 . To complete the McCarthy (1999) assumptions, we examine the effects of inflation shocks at 3 stages. Firstly, demand shocks are identified from the dynamics of the output gap and Money supply $(4,6)$, while an oil price is identified "Supply" shocks (3). Secondly, External" shocks are identified from the dynamics of exchange rate movement after taking into account the contemporaneous effects of the supply and demand shocks (5). Thirdly, we assess that the conditional expectations in equations (1)-(6) can be replaced by linear projections of the lags of our variables in the system.

\section{Data Source}

In our analysis, we Use quarterly data for seven macroeconomic variables over the period of Q1 2002 to Q1 2011. Our variables are cpi, ppi, $\mathrm{m} 2$ and oil represent cconsumer price index, producer price index, growth rate of Money supply (M2),oil prices, These variables are collected from different issues of the IMF's International. Following McCarthy (1999), $y$ is the output gap is created by taking the deviations of the log of real GDP from a linear and quadratic trend. Finally and in particular the Algerian case, we prefer to use two nominal exchange rates, US Dollar against the Algerian Dinar (US/DZ) and (Euro/DZ).

\section{Results and Comment}

\subsection{Stationarity and Cointegration tests}

Augmented Dickey-Fuller $(1979,1981)$ and Phillips and Perron, (1988) tests can help avoid false results through stationary tests of times series. Our results, drawn from the stationary test represented in table 2, allow a rejection of the null hypothesis in the first difference that signifies no stationary in all our series, but enables an acceptance at a level that signifies integration of the variables at order 1.

Table (2): Stationary test results

\begin{tabular}{|c|c|c|c|c|}
\hline \multirow{2}{*}{ Variable } & \multicolumn{2}{|c|}{ ADF } & \multicolumn{2}{c|}{ PP } \\
\cline { 2 - 5 } & Level & First Difference & Level & First Difference \\
\hline CPI & -0.99 & $-7.74^{\star \star \star}$ & -2.64 & $-8.32^{\star \star \star}$ \\
PPI & -1.94 & $-4.54^{\star \star \star}$ & -2.06 & $-4.54^{\star \star \star}$ \\
Oil prices & -3.42 & $-5.21^{\star \star \star}$ & -2.58 & $-4.77^{\star \star \star}$ \\
Output gap & -1.81 & $-4.03^{\star \star \star}$ & -3.05 & $-7.72^{\star \star \star}$ \\
M2 & -2.89 & $-6.56^{\star \star \star}$ & -2.82 & $-6.25^{\star \star \star}$ \\
EU/DZ exchange rate & -2.92 & $-5.22^{\star \star \star}$ & -2.92 & $-5.73^{\star \star \star}$ \\
US/DZ exchange rate & -2.64 & $-4.52^{\star \star *}$ & -1.64 & $-3.44^{\star \star \star}$ \\
\hline
\end{tabular}

*show values are significant at $05 \%$ level with MacKinnon (1996).

** show values are significant at 10\% level with MacKinnon (1996).

*** show values are significant at $5 \%$ and 10 level with MacKinnon (1996). 


\section{Variance Decomposition}

The Variance decomposition ${ }^{2}$ is reported in table 3,4 and shows in short and long term, percentage change of consumer price is passed to explain about $\% 3$ to $\% 28$ by EU/DZ exchange rates compared a $\% 5$ to $\% 3$ by US dollar/DZ exchange rates for a forecast horizon, whereas PPI changes to exchange rates changes is limited about $12 \%$ for euro and 5 for US dollar against the Algerian Dinar after eight years.

The magnitude contribution of demand shocks to explain CPI and PPI change is ranges from $20 \%$ and $17 \%$ after thirty quarterly, while, supply shock (oil price) continue to contribute largely to CPI fluctuations (30\%) and quite modestly to PPI (5\%).

The most result of Variance decomposition can be demonstrates that monetary shocks (exchange rate and supply money) are important sources of CPI variance (50\%). The oil important is nevertheless less strong contribution than monetary shocks. In contrast, these factors cannot explain relatively the variance of producer consumer prices.

Table (3): Variance decomposition of CPI

\begin{tabular}{|c|c|c|c|c|c|c|}
\hline Forecast horizon (Quarterly) & CPI & Output gap & Oil & M2 & US/DZ & EU/DZ \\
\hline 3 & 77 & 6.5 & 6.4 & 1.3 & 5 & 3.2 \\
12 & 48 & 3 & 20 & 10 & 4 & 13 \\
+30 & 15 & 2 & 31 & 20 & 2 & 28 \\
\hline
\end{tabular}

Table (4): Variance decomposition of PPI

\begin{tabular}{|c|c|c|c|c|c|c|}
\hline Forecast horizon (Quarterly) & PPI & Output gap & Oil & M2 & US/DZ & EU/DZ \\
\hline 3 & 87 & 5 & 3 & 2.5 & 2 & 7 \\
12 & 70 & 10.5 & 4 & 2.3 & 4.7 & 10 \\
+30 & 58 & 14 & 5 & 3 & 5 & 12 \\
\hline
\end{tabular}

\section{The Impulse Responses}

The impulse responses present the dynamic responses of the exogenous variables in relation to the time of variation of the endogenous variable (See Doan (1992), Sims and Zha (1999)). It indicates an important pass-through from exchange rate to consumer prices, but it shows in same times more sensitive pass trough of the EU/DZ exchange rate compared pass trough of the US/DZ exchange rate, when results seem incomplete pass-through takes about two quarterly in the first sub-sample period.

In long run, the magnitude pass-through of euro/DZ exchange rate to $\mathrm{CPI}$ is more than one (complete) compared $30 \%$ ranges for the US dollar IDZ exchange rate. For the main explanations can be explain these results are consist firstly by increase in world commodity prices especially between 2007 tell a half 2008 and dismantling Algerian trade barriers after the signing 3 and entered into force 4 of the Euro-Mediterranean Agreement establishing an Association without mentioning that union is the largest trading partner about $1 / 2$ of the Algerian imports, (see figure). Moreover, the Algerian Importers decide to not cut his profit margin and still the maximum profits instead decreasing imports price Krugman (1987). Finally, we concludes the rising import prices Ensue the Algerian dinar depreciation5 in the first hand and all previous explanations are the most important determinants of inflation in long and short-run (the imported inflation) when the food and manufactured goods prices represent the main Algerian imports composition (3/4). Also, Pass-through is strong and has speed increase for oil and money supply to CPI. In the contrary, it shows weak sign of Output gap to a response of domestic inflation.

In the all time Horizon, Exchange rates pass-through appears reasonably stable close to zero to PPI, which we

\footnotetext{
2 The results of cointegration test (we use trace and Max-eigen value tests) indicate that there is many long run relationship between variables included in this study at the 0.05 level.

3 In April 2002

4 In September 2005

${ }^{5}$ Between January 2003 and January 2013, the Algerian exchange rate has varied continuously; from January 2003 to September 2008, the U.S dollar depreciated monthly against the Algerian Dinar by about 19\%, followed by a depreciation of $6 \%$ during the 2008 financial crisis. Between January 2010 and January 2013 the Algerian dinar depreciated against the U.S. dollar by 4.2\%. In contrast, the Algerian dinar star less than 70 unities against the euro and finished his depreciation more than 100 unities.
} 
carried same main results while less than plus and minus 20 percent interval of producer price changes is responses through distribution chain of demand and supply shocks within thirty quarterlies.

In fact, these quite modest of pass-through on producer prices clearly reflect the Dutch Disease (Codren and Neary (1982) and Bruno and Sachs (1982)) effect on Algeria economy and highlighted how the manufacture sectors is underdeveloped and did not exceed 6\% in the last decade when Oil and gas revenues constitute the dominant income.6 On this point, we can say the exchange rates and others chains pass-through involves a small reaction on producer price index is not only affected by the Dutch Disease, but Government Algeria boost to discourage companies and investors (producer) manufacturing improvement by transferring 51\% of their capital to local partners7 while it emphasizes how the policy maker help to swell the Algerian imports instead of trying to curtailment by replacing with domestic production.

Figure 04: the impulse responses of $\mathrm{CPI}$

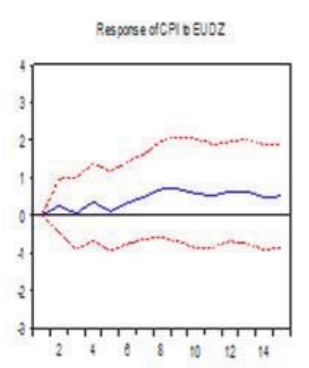

$$
\text { Responseto Choesiy OneSD Imo arons:2SE }
$$
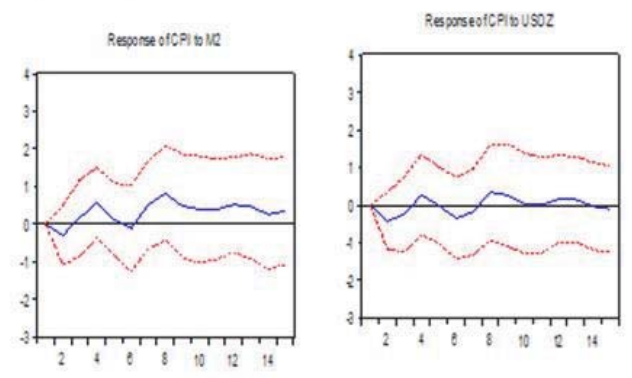

Response a CFI O OL
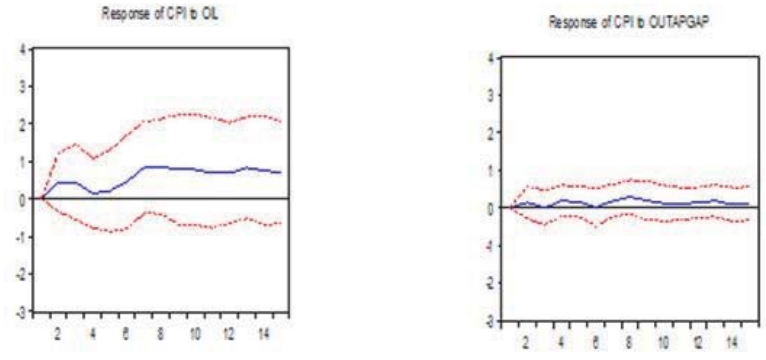

Figure 04: the impulse responses of PPI

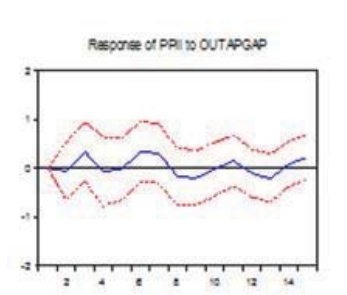

Responseto Cholesky OneS. D. movatons :2S.E
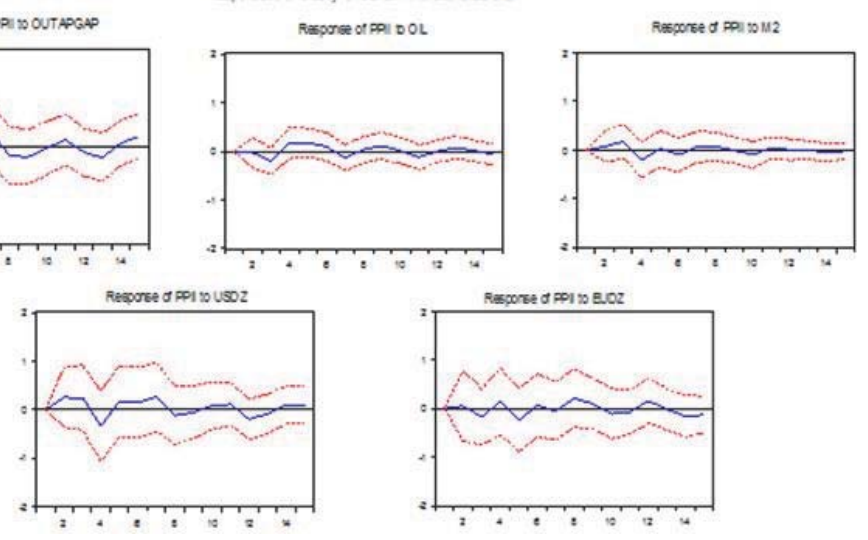

\section{Conclusion}

In this paper, we examined the exchange rate pass-through on producer and consumer price indexes in the Algerian

${ }^{6}$ Between 2002 and 2011 this sector accounted for $97 \%$ of exports, $32 \%$ to $45 \%$ of GDP and $46 \%$ to $70 \%$ of government revenue while trade openness, exhibits a high figure of $60 \%$ in the same period.

7 Ministerial instructions issued in December, 2008. 
economy compared a negligible reaction on producer price index (PPI). This contradictory situation can be explain by an increase in world commodity prices and dismantling Algerian trade barriers after entered into force of the EuroMediterranean Agreement and reflects the puzzling effect of Dutch Disease on Algeria economy.

\section{References}

Abdelnacer Bouteldja et al, 2013, The Black Market Exchange Rate and Demand for Money in Algeria" International Journal of Arts and Commerce Vol. 2 No. 10 November, 2013, pp71-82.

Belaisch Agnes, "Exchange Rate Pass - Through in Brazil ", Working Paper, No 03/141, IMF , Western Hemisphere Department , USA, 2003.

Billmeier, A and Bonato L, " Exchange Rate Pass- Through and Monterey Policy in Croatia " Working Paper, No 02/109, IMF European Department, USA, 2002

Choudhri, E. V., and Hakura D. S.," Exchange Rate Pass-Through to Domestic Prices : Dose the Inflationary Environment Matter? " , Working Paper, No 01 / 194 , IMF , IMF Institute, No.01 / 194,s USA , 2001

CAMPA, J. and L. GOLDBERG (2005),"Exchange rate pass-through into import prices", The Review of Economics and Statistics, 87 (4), $679-690$.

Dickey, D.A. and Fuller, W.A., (1979). " Distribution of the Estimators of Autoregressive Time Series with a Unit Root." Journal of American Statistical Association, Vol 74, No. 366a, 427-431.

Doan, T. (1992): Rats user's manual, version 4, Evanston

Etsuro Shioji, 2012. "The Evolution of the Exchange Rate Pass-Through in Japan:A Re-evaluation Based on Time-Varying Parameter VARs," Public Policy Review, Policy Research Institute, Ministry of Finance Japan, vol. 8(1), pages 67-92, June.

Ghosh, A. and Rajan, R.S., 2007. Macroeconomic Determinants of Exchange Rate PassThrough in India. Colorado College Working Paper 2007-02.

Gold, F, I and Werlang, S.R.C., " The Pass - Through from Depreciation to Inflation : A Panel Study " Banco Central de Brasil, Working Paper, No 5, 2003.

Goldberg, Pinelopi Koujianou and Michael M Knetter (1997): "Goods Prices and Exchange Rates: What Have We Learned?" Journal of Economic Literature, Vol. 35, No. 3, pp. 1243-72.

Guerorguiev, Nikolay, "Exchange Rate Pass - Through in Romania", Working Paper, No 03/130 IMF, European Department, USA, 2003.

Janine A et al (2012), Exchange Rate Pass-through to Import Prices, and Monetary Policy in South Africa, South African Reserve Bank Working Paper, September, 2012

Kamel . S et al; (2014) The relationship between oil price and the Algerian exchange rate, Topics in Middle Eastern and African Economies, Vol. 16, No. 1, May 2014.

Khundrakpam J. K. ,"Economic Reforms and exchange rate pass-through to domestic prices in India," BIS Working Papers No. 225, February, 2007.

Krugman, P (1987): "Pricing to market when the exchange rate changes", in: S Arndt and J Richardson (eds), Real-financial linkages among open economies(Cambridge: Massachusetts: MIT Press).

Leigh, D and M Rossi (2002): "Exchange rate pass-through in Turkey", IMF Working Paper No 02/204 (Washington: International Monetary Fund).

McCarthy, J., " Pass-Through of Exchange Rate and Import Prices to Domestic Inflation in Some Industrialized Economies " , BIS Working Papers, No. 79 - November 1999.

Nidhaleddine Ben Cheikh, (2013), The Pass-Through of Exchange Rate in the Context of the European Sovereign Debt Crisis, FIW Working Paper $\mathrm{N}^{\circ} 123$, June 2013

Phillips P.C.B. and Perron P. (1988). "Testing for a Unit Root in Time Series Regression." Biometrika, Vol. 75, 335-346

Rudrani Bhattacharya, Ila Patnaik and Ajay Shah (2008), Exchange Rate Pass-through in India; National Institute of Public Finance and Policy, New Delhi March 27, 2008

Siaw F and Anokye M. A, (2010), Exchange Rate Pass-Through in Ghana, International Business Research, Vol. 3, No. 2; April 2010

Shintani, Mototsugu \& Terada-Hagiwara, Akiko \& Yabu, Tomoyoshi, 2013. "Exchange rate pass-through and inflation: A nonlinear time series analysis," Journal of International Money and Finance, Elsevier, vol. 32(C), pages 512-527.

Sims, C. A. and Zha T. (1999). "Error Bands for Impulse Responses." Econometrica. Vol. 67, 1113-1155.

Verena T et al (2012) Exchange Rate Pass Through to Domestic Prices: Evidence from Mauritius, ICITI in web: http://sites.uom.ac.mu/ wtochair/images/stories/cProceedings12/N.TandrayenRagoobur_Exchange_Rate_Pass_Through_in_Mauritius_AEID.pdf

Takhtamanova ,Y. (2008). Understanding Changes in Exchange Rate Pass-Through Federal Reserve Bank of San Francisco Working Paper 2008-13 Federal Reserve Bank of San Francisco, San Francisco. 